\title{
Turkey's Search for a Third Party Role in Arab-Israeli Conflicts: A Neutral Facilitator or a Principal Power Mediator?
}

\section{Meliha Altunisik \& Esra Cuhadar}

To cite this article: Meliha Altunisik \& Esra Cuhadar (2010) Turkey's Search for a Third Party Role in Arab-Israeli Conflicts: A Neutral Facilitator or a Principal Power Mediator?, Mediterranean Politics, 15:3, 371-392, DOI: 10.1080/13629395.2010.517101

To link to this article: https://doi.org/10.1080/13629395.2010.517101

曲 Published online: 19 Nov 2010.

Submit your article to this journal $\widetilde{ }$

Џلll Article views: 849

Citing articles: 7 View citing articles ๘ 


\title{
Turkey's Search for a Third Party Role in Arab-Israeli Conflicts: A Neutral Facilitator or a Principal Power Mediator?
}

\author{
MELIHA ALTUNISIK* \& ESRA CUHADAR** \\ *Department of International Relations, Middle East Technical University, Ankara, Turkey; \\ **Department of Political Science, Bilkent University, Ankara, Turkey
}

ABSTRACT This paper examines Turkey's increasing involvement in the Israeli-Syrian and Israeli-Palestinian conflicts as a third party in the last decade. The paper first discusses the underlying reasons and motivations behind the change in Turkish foreign policy. In this section we answer the following question: While the traditional Turkish policy in the Middle East was nonintervention, what factors contributed to this recent change? We discuss these as systemic factors and domestic factors. In the second section of the paper we summarize the theoretical literature on third party intervention and mediation especially focusing on strategies, modes, activities, and tactics used. This section lays the background for the following section which classifies the various Turkish third party strategies and activities in the Israeli-Syrian and Israeli-Palestinian conflicts so far. In the final section we focus on the challenges to this new Turkish role from Turkish, Israeli, and Arab perspectives. We also discuss the crises between Israel and Turkey in the last year and how they constitute a barrier to Turkey acting in an effective third party role.

\section{Introduction}

One of the new turns in Turkish foreign policy in recent years has been the eagerness to play third party roles in regional conflicts. After several failed attempts Turkey was able to bring Israel and Syria for indirect talks in Istanbul in 2008. Ankara, more than once, announced its willingness to mediate in the Iranian nuclear issue, and once facilitated a meeting in Istanbul between EU foreign policy chief Javier Solana and Iran's then top nuclear negotiator, Ali Larijani, in April 2007. Right before the national elections in Iraq in 2005, Sunni groups were invited to Istanbul to convince them to participate in the political process, with considerable success. Turkey also decided to send forces to Lebanon as part of United Nations Interim Force in Lebanon (UNIFIL II)

Correspondence addresses: Professor Meliha Altunisik, Department of International Relations, Middle East Technical University, Ankara, Turkey. Email: maltunis@metu.edu.tr; Assistant Professor Esra Cuhadar, Department of Political Science, Bilkent University, Ankara, Turkey. Email: esracg@bilkent.edu.tr 
and, together with Qatar, helped broker the Doha agreement in May 2008 which ended the political deadlock in that country. Similarly Ankara was involved in the Gaza ceasefire negotiations, reconciliation efforts between Hamas and Fatah, and tried to facilitate negotiations between Iraq and Syria. Although not all of these efforts resulted in successful outcomes, Turkey's eagerness to play these roles requires close attention.

Turkey's new activism in the Middle East is all the more significant as it is in contrast to Turkey's long-held policy of not getting involved in regional conflicts (Robins, 1991: 65). Especially in recent years Turkey has adopted a conflict resolution/peace building agenda in the Middle East region (Davutoglu, 2008). ${ }^{1}$ As articulated by the current Justice and Development Party (Adalet ve Kalkınma Partisi, AKP) government's foreign minister, Professor Ahmet Davutoglu, this new agenda is based on principles such as 'security for all, dialogue and inclusiveness' and an increasing emphasis on civil society-to-civil society in addition to state-to-state relations. However, this new role assumed by Turkey and its implications have not adequately been addressed so far. This paper aims at fulfilling this void by solely focusing on Turkey's involvement as a third party in the Israeli-Palestinian and Israeli-Syrian conflicts.

We first discuss the reasons for this new activism in Turkey's approach to Middle East conflicts. Then we provide a brief overview of the various third party roles Turkey has so far assumed in the Israeli-Syrian and Israeli-Palestinian conflicts. Finally, we assess Turkey's third party role in these conflicts in light of the following questions: In view of the recent developments in Turkish-Israeli relations, is Turkey changing its third party intervention strategy? Is the nature of Turkey's third party role transforming from a neutral facilitator to a principal power mediator?

\section{Understanding Change in Turkey's Stance towards Arab-Israeli Conflicts}

We argue that Turkey's new stance towards the regional conflicts in the Middle East is a result of both international systemic and domestic political factors. The new stance began to emerge in the Turgut Ozal period, particularly during the Gulf crisis. Ozal, who was prime minister between 1983 and 1989 and then president between 1989 and 1993, promoted extensive involvement in the Middle East, despite the criticisms from the opposition parties, the bureaucracy, and the public, demonstrating that he was not reluctant to participate in intra-Arab conflicts. Later during coalition governments led by Bulent Ecevit and Mesut Yilmaz, foreign minister Ismail Cem (1997-2002) was eager for Turkey to play the role of a facilitator especially in the Israeli-Palestinian conflict. Several initiatives to that effect mainly remained inconsequential (Guven, 2001; Kohen, 2001; Zaman, 2002). The new approach intensified and became more systematic during the AKP government. The new government's eagerness to play such roles coincided with the opportunities in the regional context.

\section{The Systemic Reasons for Change}

Numerous changes in the international system and the regional dynamics beginning with the 1990s have affected Turkey's new orientation towards the Middle East conflicts. 
The end of the cold war has afforded new opportunities for activism while at the same time presented new policy challenges. The reshaping of Turkey's geopolitical space also opened up new vistas for Turkey by providing an opportunity to use its cultural and historical assets to influence nearby regions. Turkey's new geopolitics also meant that it was surrounded by unstable states and regions, endemic with armed conflicts that risk spilling over across its borders. In the post-cold war environment, regional powers like Turkey are increasingly expected to address regional problems.

The existence and intensity of regional conflicts led Turkey to become more conscious of its regional roles. Increasing instability in the region (the Gulf Wars, the collapse of the Peace Process, the Israeli attack on Lebanon in 2006 etc.) presented security challenges for Turkey. Through active mediation and facilitation of regional disputes, Turkey hoped to enhance its own security as well. The state elites emphasized that the Arab-Israeli conflict created instability and led to a constant threat of war and radicalism in the region. Especially after the second Intifada and the Israeli operation in Gaza, the Israeli-Palestinian conflict has become a priority issue for Turkish policymakers. This was a shared view in different segments of the Turkish political elite including the military and the Ministry of Foreign Affairs. ${ }^{2}$ For example, in a speech the Chief of Staff Ilker Basbug said: 'Without a resolution of the Palestinian question, there could be no peace in the Middle East' (quoted in Toksoz, 2009: 88).

The fact that Turkey is seen as a relatively neutral country that both sides have good relations with and as having important human and material resources that can boost the peacemaking efforts has been emphasized by the parties and it has become an advantage for Turkey to play this role actively (Cuhadar, 2007). The improvement of relations between Turkey and Israel beginning in mid-1990s made it possible for Turkey to assume such a third party role. This relationship evolved throughout the last decade rather rapidly with the burgeoning economic relations and the signing of a free trade agreement, increasing cooperation in cultural and educational issues, and perhaps most importantly with the signing of several agreements advancing security cooperation between the two countries (Altunisik, 2000). The rapprochement between Israel and Turkey coincided with the Middle East peace process. This by itself eased the Turkish-Israeli relations by relieving Turkey from the burden of striking a delicate balance between Israel and Arabs in the Middle East (Altunisik, 2000: 173).

One other major regional development that paved the ground for a more active Turkish involvement was the 2003 Iraq War. The war transformed the regional geopolitical landscape in several ways. An immediate consequence was the intensification of intra-Arab divisions and the emergence of a vacuum in regional politics. In this context the decline of traditional Arab powers, such as Egypt, left room for non-Arab countries like Turkey and Iran to fill in this regional vacuum.

The post-Iraq War policies of the US in the region deepened this vacuum and broadened the room for Turkish and Iranian involvement. The Bush administration failed to create a Middle Eastern order. Unlike during the Clinton administration the Israeli-Syrian and Israeli-Palestinian peace process was left largely unattended. Although the Obama administration promised a more active 
involvement in the resolution of these conflicts, so far it has not been able to introduce a policy change.

The new regional geopolitics also created dilemmas for Syria. While being isolated and threatened by the Bush administration on the one side, and experiencing a difficult domestic transition under Bashar Assad on the other, Syria constituted a major vulnerability for regional and Turkish security. Turkey's improving relations with Syria after 2000 offered a viable way out from its sole dependence on Iran and the opening of a path to reach out to the West.

In the post-2003 Middle East, Iran's influence in the region increased significantly especially as Iran became a major actor in the reshaping of Iraq. Iran also indirectly influenced Lebanese and Palestinian politics through its links to Hezbollah and Hamas respectively. Iran's increasing impact was perceived as a threat by the Sunni Arab countries and Israel. Their discomfort with Iran led to a more welcoming attitude towards Turkish involvement in the regional conflicts. Unlike Iran, Turkey, due to being able to talk to all the parties in the region, was perceived as a fair interlocutor and a credible third party (Altunisik, 2010: 14). Thus, third party roles in the Middle East conflicts allowed Turkey to fill the vacuum created by the collapse of the peace process, inter-Arab divisions, US inability, and to counterbalance Iran's rising influence.

Finally, the EU enlargement has become a factor that also contributed to Turkey's eagerness to play third party roles. Since gaining candidate status at the 1999 Helsinki Summit, Turkey has launched a harmonization process both in terms of its positions on issues as well as its foreign policy tools. The Turkish Foreign Ministry announced that it achieved 95 per cent harmonization, which was reiterated by the progress reports of the European Commission (Commission of the European Communities, 2003). This process led to norm diffusion in foreign policy as well, and Turkey began to adopt EU foreign policy soft power tools such as facilitation in dealing with conflicts (Altunisik, 2009a: 149-50). The EU Commission's progress reports on Turkey acknowledged and praised Turkey's performance in this regard (Commission of the European Communities, 2006: 71-2, 2007: 74-5).

\section{Domestic Reasons for Change}

Apart from the factors at the systemic level, various domestic political and economic developments enhanced Turkey's regional position and encouraged Turkey to undertake a third party role in the region.

Between 2002 and 2007 Turkey had the highest average annual per capita growth rate as well as the highest cumulative growth rate in its region. Table 1 shows Turkey's growth indicators during this period as compared to some of the neighbouring countries and to several Western economies.

Economic indicators concerning foreign trade also show improvement in the Turkish economy between 2002 and 2007. Turkey's exports were not only higher than the neighbouring countries, but also increased steadily between 2002 and 2007, as can be seen in Table 2. Moreover, Turkey's trade with the Middle Eastern countries improved significantly. While in 1996 Middle East's share of Turkey's 
Table 1. Per capita growth rate of Turkey compared with other countries (2002-07)

\begin{tabular}{lcc}
\hline Countries & Average annual growth rate 2002-2007 & $\begin{array}{c}\text { Cumulative growth rate 2002-2007 } \\
(\%)\end{array}$ \\
\hline Turkey & $\mathbf{5 . 2 0}$ & $\mathbf{3 5 . 6 1}$ \\
Iran & 4.47 & 30.02 \\
Israel & 1.81 & 11.38 \\
Greece & 4.33 & 29.01 \\
USA & 1.62 & 10.17 \\
UK & 2.59 & 16.62 \\
\hline
\end{tabular}

Source: Heston et al., (2009).

trade was 9 per cent, by 2008 it had increased to 19 per cent (Sak cited in Altunisik, 2010: 23).

This transformation not only led to Turkey's new image as a civilian-economic power, in addition to its already existing military might, but also led to increasing self-confidence. These developments translated into more constructive foreign policy roles for Turkey, led to improvement in Turkey's relations with its neighbours and to the emergence of a more positive image of Turkey in the region (Aras and Polat, 2007).

Turkish public opinion has traditionally been sympathetic towards the Palestinian cause (Esmer, 2009). In a recent public opinion survey conducted in early 2010, Esmer found that after Azerbaijan (6.89 out of 10), Palestine (5.77 out of 10) is the second highest ranking nation towards which Turkish citizens feel warmth and affinity (Esmer, 2009). At the same time, Turkish citizens' feeling of warmth and affinity towards Israel ranks very low (1.15 out of 10). The pro-Palestinian feelings of the Turkish public have been an influential factor for the domestic constituencies of both the governing and opposition parties. Furthermore, the Palestinian issue has been a major concern particularly for more conservative people that constitute the core supporters of the AKP. This situation has reinforced the AKP's interest in this conflict and encouraged Turkey to become more involved. The conservative constituency became more mobilized after Israel's Gaza operation and the embargo imposed afterwards. In the spring of 2010 several Islamic-affiliated grassroots civil society organizations from Turkey organized with some international participation to challenge the blockade on Gaza. An international aid flotilla was organized with

Table 2. Real exports in USD (2000 base year) 2002-07

\begin{tabular}{lcccccc}
\hline Countries & 2002 & 2003 & 2004 & 2005 & 2006 & 2007 \\
\hline Turkey & $\mathbf{5 . 9 7}$ & $\mathbf{6 . 3 8}$ & $\mathbf{7 . 0 9}$ & $\mathbf{7 . 6 5}$ & $\mathbf{8 . 1 5}$ & $\mathbf{8 . 7 5}$ \\
Greece & 2.86 & 2.96 & 3.37 & 3.51 & 3.89 & 4.02 \\
Iran & 2.45 & 2.72 & 2.7 & 2.88 & 3.03 & 3.11 \\
Israel & 4.03 & 4.35 & 5.11 & 5.33 & 5.65 & 6.18 \\
\hline
\end{tabular}

Source: Data taken from World Bank World Development Indicators (2010). 
the Turkish leadership and was sent to Gaza. The flotilla was stopped by an Israeli military raid in which nine Turkish citizens were killed. This incident demonstrated the extent to which the conservative constituency of the AKP cared about the issue and pushed the government to get involved.

The increasing eagerness of Turkey to play a third party role is also related to the emergence of new ideas about Turkey's foreign policy identity and new political cadres. Since the end of the cold war a debate started as to what should be Turkey's foreign policy identity in the constantly shifting regional and global balances. One very commonly accepted idea in the post-cold war foreign policy discourse was that Turkey was a 'bridge' between different civilizations and East and West (Yanik, 2009). Turkish policymakers liked using the 'bridge' metaphor which not only granted 'uniqueness' and 'exceptionalism' to Turkish identity, but also legitimized a 'go-between' position between different worlds or civilizations (Yanik, 2009: 532). The bridge metaphor provided a suitable framework for third party activities as well, which encompassed notions like 'impartiality', 'in-betweenness', and reaching out to 'all sides'.

This debate about Turkish identity was very much related to Turkish foreign policy in the Middle East too. Some politicians began to criticize the traditional Turkish foreign policy of non-intervention and offered alternative worldviews. But some of these ideas found a chance for more extensive implementation during the reign of the AKP and its political cadres. Thus the impact of the AKP and its vision of Turkey's foreign policy in the Middle East has been a very important factor in Turkey's eagerness to play third party roles in the Middle East. Since coming to power in 2002, the AKP has been developing a new vision vis-à-vis the Middle East. This new vision is based on a criticism of the dominant perspective of Turkey's Middle East policy for being too isolationist, passive, and over-securitized. In contrast to this perspective, the AKP's vision emphasizes historical and cultural ties with this region and the utilization of soft power tools. The AKP's cadres argue that common history and identity are positive factors that not only make it easier for Turkey to be involved in this region, but also force Turkey to be more active. On various occasions AKP leaders have mentioned Turkey's responsibility in the Israeli-Palestinian conflict with special reference to Ottoman rule in the region. For example, during an official visit to Israel the then foreign minister, now president, Abdullah Gul said: 'Turkey has a special responsibility to contribute to peacemaking efforts as the grandchildren of an empire that ruled Jerusalem in peace for 600 years and that had friendly historical relations with both Israelis and Palestinians' (Radikal, 2005a).

The conceptual framework of this new vision can be found in the writings of the current foreign minister Ahmet Davutoglu (2008). Davutoglu argues that as a result of the historical legacy of the Ottoman Empire, Turkey possesses great geographical depth in its neighbouring regions including the Middle East. This historical and geographical depth places Turkey at the centre of these regions and endows the country with extensive influence which it should use. Therefore, the new vision calls for an activist engagement with the regional systems around Turkey. This involvement also entails mediating regional conflicts similar to the Ottoman system 
which was based on the understanding of a just and impartial third party (Murinson, 2006: 945). For instance, referring to the conflict over Jerusalem, Davutoglu argued that "no political problem in the region can be resolved without Ottoman archives that Turkey inherited but did not pay due respect to' (quoted in Altunisik, 2009b: 187; Davutoglu, 2001).

The new ambitions to be more active in the Middle East and to play a mediator role complemented each another to pave the ground for Turkey's re-entry into Middle East politics as a pro-active regional actor. By being more active and mediating, Turkey could not only diminish the security risks in its region emanating from the Arab-Israeli conflicts, but would also gain prestige as an important actor.

\section{Turkey's Third Party Role in the Israeli-Palestinian and Israeli-Syrian Conflicts}

In this section we first discuss a conceptual framework to place Turkey's third party activities in perspective. Then we dwell on the specific third party roles assumed by Turkey. Finally, we elaborate on the challenges faced in the implementation of these activities.

The literature on mediation provides several frameworks that categorize the wide range of strategies and activities used by third parties. One important categorization is concerned with different intervention strategies. Stern and Druckman (2000: 5), Crocker et al., (1999), and Beriker (2008) suggest structural prevention and conflict transformation/social-psychological as two distinct strategies.

Structural prevention refers to institution building efforts of third parties in a conflict, such as contributing to the development of social capital, establishing and maintaining legal and political institutions that offer incentives for the non-violent waging of the conflict and negotiations, and conflict-sensitive development assistance. This strategy implies that mediation is more than just assisting conflicting parties in reaching a negotiated solution; it also includes activities that create a conducive environment for the conflicting parties to change their rational calculations about a negotiated settlement. Institution building and capacity building (and their withdrawal or the threat of their withdrawal) can be offered by the third party as side payments or incentives to create an environment conducive to negotiations.

Conflict transformation/social-psychological approaches to third party intervention, on the other hand, is a strategy that focuses on communication processes and relationship building in order to transform and change the perceptions and attitudes of the conflicting parties towards the conflict and towards each other. Third parties help the disputants reconcile by helping them redefine their interests and needs.

To these strategies - different from Crocker et al., (1999) - Stern and Druckman (2000: 5) add a third one: power mediation. This third strategy combines mediation with power (usually hard power) based instruments.

A more elaborate categorization of third party roles in structural prevention and conflict transformation can be found in Beriker (2008). According to Beriker, the conflict transformation strategy includes the instruments of facilitative mediation, 
interactive conflict resolution, conflict resolution training, and post-conflict rehabilitation. On the other hand, Beriker suggests that positive incentives, peacekeeping, initiating bilateral co-operative programmes and capacity building, negative inducements and power mediation are the third party instruments used in structural prevention. In this paper, we treat power mediation, as suggested by Beriker, as an instrument of structural prevention.

A third party can adopt either one of these strategies or mix several of them during the different stages of a conflict. In fact, contingency theory suggests that different types of third parties are more appropriate at different stages of a conflict (Keashly and Fisher, 1996). Certain states/actors are more capable of implementing one strategy because of their identity, power capabilities and material resources. For instance, mediation efforts that are held by great powers with higher power capabilities are more likely to successfully implement power mediation, whereas a soft power tends to favour a conflict transformation strategy.

Besides strategies, several scholars identify the types of mediation. In its implementation, mediation can be carried out in a way that reflects one or more of the strategies mentioned above: structural prevention or conflict transformation.

Along these lines a useful categorization of mediation was offered by Zartman and Touval (1996) and Bercovitch (1992), in which they grouped the functions of an international mediator into three types: communicator/facilitator, formulator, and manipulator (power mediation). In the first type, the mediator simply assists the communication process between the parties. A communicator/facilitator type mediator often adopts a social psychological/conflict transformation strategy.

As a formulator the mediator aims at generating a mutually acceptable formula for a negotiated solution. A manipulator type mediator not only formulates a plan, but also uses its power to push and pull the parties towards an agreement. A manipulator is also called a power mediator; an activity that falls into the domain of power politics and often combined with structural prevention to create a conducive environment for a negotiated settlement.

In categorizing the types of mediators as such, two dimensions are often taken into account and conceptualized by various scholars. These are impartiality and power. One of the earlier theoretical conceptualizations in this regard has been provided by Princen (1992: 24) as 'principal' and 'neutral' mediators. While principal mediators have interests in the disputed issues and can bring resources to the dispute settlement process; neutral mediators neither have an interest in the outcome of the dispute nor have the resources that can be used to offer inducements. Principal and neutral mediators use different tactics in negotiation (Princen, 1992: 23). While the principal mediator does not abstain from bargaining, striking a side deal, or forming a coalition with one of the disputants to put leverage on the other party and to get what they want, neutral mediators refrain from using such tactics and rather focus on the communication and interaction between the disputants to make sure that the process and the agreement is fair, durable and efficient.

Siniver further suggests that power and impartiality are closely linked to one another in a way that the occurrence of one in mediation is often described by the absence of the other (Siniver, 2006: 809). Therefore, theoretically, a third party can 
simultaneously possess power/resources and neutrality, but in practice, according to several scholars (e.g. Princen, 1992; Siniver, 2006), these two characteristics are mutually exclusive. Often powerful mediators (or read principal mediators) intervene in the substance and use rewards and punishments more and do not refrain from using their leverage on the parties unequally. On the other hand, in facilitative mediation (or read neutral mediation) the mediator refrains from asserting power and its strength is derived from its impartiality and procedural expertise (Carnevale, 2002; Siniver, 2006). Procedural expertise refers to the facilitator's conduct of a fair process and impartiality of the procedures employed at the negotiation table. For facilitators, impartiality is an expected characteristic, whereas for a power mediator it is the ability to use power and leverage. Each style has advantages and disadvantages as suggested by the contingency theory (Keashly and Fisher, 1996). A principal and power mediator can use leverage, rearrange pay-offs, offer inducements, etc., whereas a neutral facilitator helps with communication and encourages joint problem-solving, building of trust and empathy between the disputants with little political risk (Princen, 1992: 26). One can classify the range of mediation practices along the dimensions of impartiality and power as in Figure $1 .{ }^{3}$

Another theoretical dimension of third party intervention is the types of activities undertaken by the third party. Kriesberg $(1996,2001)$ identified these activities as follows: helping arrange the agenda and selecting negotiating parties, providing a safe space for meetings, conveying information between the parties, increasing resources for settlement, reframing the conflict as a joint problem to be solved, suggesting options, helping the parties discover new options, raising costs of failing to de-escalate, helping to create parity, helping the parties to implement agreements, and fostering reconciliation.

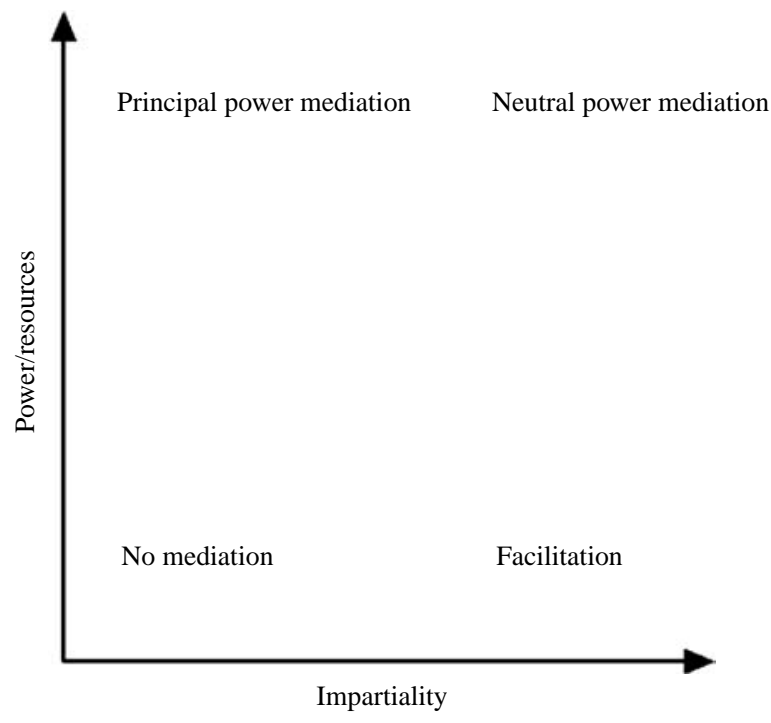

Figure 1. Types of mediation (power and neutrality) 
According to Kriesberg (2001: 78) certain mediators are more apt to play one or more of these roles, and some of these roles may be incompatible for a specific third party at a specific time. For example, raising the costs of failing to de-escalate is more successfully accomplished by a third party in the manipulator/power mediator mode, because it requires leverage and resources. On the other hand, helping to arrange an agenda and suggesting options are roles more suitable for a formulator type mediator. Providing a safe space and conveying information are some of the important roles often best played by a facilitator type mediator.

\section{Where does Turkey's Third Party Role Fit in?}

Most of the third party activities undertaken by Turkey can either be characterized as conflict transformation and facilitative mediation or structural prevention.

Conflict transformation strategy and facilitative mediation. Some of the recent highlights of this type of third party involvement are facilitation of talks between Israel and Syria, hosting Israeli and Palestinian presidential meetings in Ankara in November 2008, facilitation efforts between Fatah and Hamas, and supporting the negotiation of a ceasefire in Gaza.

It was after the second Intifada broke out and relations between Turkey and Syria improved after 2000 that the idea of Turkey becoming a facilitator in Arab-Israeli conflicts began to gain significance. Turkey's good relations with Israel, Syria and Palestinians were seen as an asset that could work in their favour. For instance, the Israeli government often asked Turkey to convince the Palestinians to renounce terrorism and stop resorting to violence (Sabah, 2000; Jerusalem Post, 2001). Likewise, the Palestinian government asked Turkey to convince Israel to get back to the negotiating table or to end specific military operations (Zaman, 2001).

However, for a long time Turkey struggled to decide whether to get involved or not and to define the nature of the third party role suitable for it. During the coalition government of Democratic Left Party (DSP) - Nationalist Action Party (MHP) Motherland Party (ANAP), foreign minister Ismail Cem gave mixed signals about Turkey's willingness to become a facilitator. Cem declared after a trip he made to the region in October 2001 that 'Turkey is not a mediator and our goal is just to make a humble contribution to help bridge the differences between Israelis and Palestinians' (Yeni Safak, 2001). With a similar perspective, Cem made a trip to Israel and Palestine together with Greek foreign minister George Papandreou in April 2002 in order to convince the parties to engage in dialogue and get back to the negotiation table. During those days, Turkey's possible mediation in the Israeli-Palestinian conflict was discussed in the media quite often. Various media correspondents used the terms mediator and facilitator interchangeably, which also indicated that there was confusion about the type of mediation intended. The issue of Turkey's mediation was also discussed between Israeli and Turkish delegations at the Foreign Ministry level (Vatan, 2002). However, Turkish authorities declared that the situation is not ripe for a mediator role similar to that conducted during the Oslo peace process. Eventually Turkey preferred to present its go-between efforts to bridge the differences as facilitation. 
The nature of Turkey's third party role remained ambiguous for a while also because not always all the parties and the other mediators were enthusiastic about Turkey's involvement in the Arab-Israeli conflicts (Cuhadar, 2007: 101). For instance, while Turkey was a member of the Mitchell Commission established after the Intifada, it did not become a part of the Quartet. Israel, and especially PM Ariel Sharon, was reluctant about Turkey's mediator role from the beginning.

As opposed to the haphazard efforts of the previous coalition government, immediately on coming to power in 2002, the AKP picked up on the issue and explored the possibility of Turkey mediating in the Israeli-Palestinian and Israeli-Syrian conflicts. PM Recep Tayyip Erdogan on several occasions sent envoys to Israel and openly declared Turkey's desire to become a mediator (Vatan, 2005). Around 2005 Israel's reluctance to accept Turkey's more active involvement began to dwindle, especially concerning Syria. Compared to the Israeli-Palestinian track, there was more willingness on the part of the parties for Turkey's role regarding the Israeli-Syrian conflict. On the Palestinian track, however, Israel preferred a more limited third party involvement from Turkey, especially restricted to the areas of people-to-people diplomacy and development projects.

Concerning Syria, Abdullah Gul, then foreign minister, began facilitating communication between Syria and Israel as early as 2005, but these efforts culminated in indirect talks only in 2008. Turkey conducted five rounds of indirect talks in Istanbul until December 2008. The parties came close to an agreement but especially the expectations for a Democrat president in the US led parties to slow down the process. In December 2008, during Israeli prime minister Ehud Olmert's visit to Turkey, the Turkish side tried to tackle the remaining obstacles to the process, but the initiation of the Gaza operation four days after the visit ended the process without a major outcome.

What specific facilitation activities did Turkey undertake? One common activity was providing a safe space for meetings. This was the case in the Ankara Forum where Palestinian and Israeli businesspeople were brought together for dialogue, in the meeting of Shimon Peres and Mahmoud Abbas in November 2007 in Ankara, and most importantly during the Syrian-Israeli talks.

Conveying information and messages between the parties to solve problems and explain the rationale for the behaviour of the other side is another common activity undertaken by facilitators. This was frequently performed by Turkey in the IsraelSyria talks. Turkey was also instrumental in conveying information and messages between Israel and the Palestinian parties, especially Hamas, for ceasefire talks during Israel's Gaza operation in December 2008. Turkey even created a special post in 2004, represented by the former minister Vehbi Dincerler, to facilitate communication between the parties.

As part of facilitation, Turkey has also assumed roles in inquiry and observation missions. Turkey was active in the Mitchell Commission that convened after the outbreak of the second Intifada in 2000. A more recent example can be given from the observatory role assumed by Turkey in a Jerusalem technical committee in 2007. Prime minister Ehud Olmert accepted Turkey's observatory role after a flare of tensions in Jerusalem due to an archaeological excavation. Such observatory and informationgathering missions are also critical to monitor and help parties implement agreements. 
Another key facilitation activity, albeit performed less frequently, was helping the parties discover new options and lobbying for these options. During the Israel-Syria indirect talks, the Turkish side brought up some options to bridge the differences between the parties. Turkey also lobbied on behalf of the US, the EU, the Quartet, and the Arab countries in order to move the negotiations and peace-making efforts forward. This role becomes more significant especially when peace negotiations begin to move. Turkey undertook this role during the initiation of the Annapolis process in 2007 and also during George Mitchell's, the Obama appointed special envoy to the Middle East, and Secretary of State Hillary Clinton's visits to the region and to Turkey in early 2009.

Structural prevention. Besides facilitation, activities that fall under the structural prevention strategy have also become visible in the last decade. However, these activities did not include power mediation. Rather, for a long time Turkey preferred introducing additional resources to the conflict and assisting conflict-sensitive development projects to create an environment conducive to peacemaking. Such activities were more welcomed by the Israelis. Israeli authorities warmly received economic development and cooperation projects initiated by Turkey and encouraged Turkish authorities to undertake more of such initiatives.

The most prominent activity of this kind is the 'Industry for Peace' initiative undertaken by the Turkish Union of Chambers and Commodity Exchanges (TOBB), first in Gaza and then in the West Bank. The initiative started following Israel's withdrawal from Gaza and with the support of Israeli, Palestinian and Turkish governments. TOBB has taken over the management of the initiative in order to attract investment in the area that will provide employment to hundreds of Palestinians. After Hamas' takeover of Gaza, the TOBB project moved to a new location in the West Bank. The project is still in the planning stage. The initiative is a good example of 'conflictsensitive development'. Such development projects incorporate a conflict transformation mechanism as well promoting cooperation and improving relations between the parties. ${ }^{4}$ The TOBB project not only aims to contribute in terms of employment, private sector development, and economic and social capacity building in Palestine, but it also increases security for Israel.

Besides the Industry for Peace project, several other structural prevention initiatives have gained momentum in recent years. Turkey's development and aid agency, the Turkish International Cooperation Agency (TICA), opened a permanent office in the Palestinian territories in 2005 and the number of development projects including the building of schools and hospitals increased especially in the West Bank (Radikal, 2005b). There are also several projects in the works, such as the possibility of building a water, gas and oil pipeline to Israel and Gaza from Turkey. Another example is the building of a health centre and a vocational training school by Bilkent University in the north of the West Bank that is accessible to both Israelis and Palestinians (Zaman, 2008). Yet, again with the Hamas takeover of Gaza and the Israeli operation in December 2008, as with facilitation, Turkey's structural prevention initiatives slowed down. 


\section{The Transformation of Turkey's Third Party Role?}

Turkey's third party efforts in the Arab-Israeli conflicts faced several challenges from the beginning. The first challenge relates to how Turkey's efforts were received by the conflicting parties and other international actors.

Turkey's ambitions were not always received warmly by the Israeli leadership (Milliyet, 2005). There have been different stances towards Turkey's role in the Israeli political circles (CNN Turk, 2009; Jerusalem Post, 28 December 2009c). In general Kadima and Labor leaders, such as Ehud Olmert from the former and Shimon Peres and Benjamin Ben-Eliezer from the latter, were more favourable towards Turkey's role. The right-wing Israeli parties and leaders, on the other hand, have usually been more sceptical about Turkey's involvement, but became outright opposed after the AKP government's critical stance towards Israel during the Gaza War. The second challenge has been the nature of the Turkish third party role. Even those who favour a more active Turkish role still preferred a limited involvement in the Palestinian track and a more active involvement in the Syrian track.

Some Arab parties, too, were reluctant to support Turkey's mediator role in the Middle East. Palestinian President Mahmoud Abbas was uncomfortable with Turkey's role especially after Turkey's communication with Hamas intensified. Egypt also had an ambiguous attitude; while on the one hand it benefited from the fact that Turkey had open communication channels with Hamas, on the other hand Cairo was concerned with the fact that Turkey's activism could overshadow its own role in the conflict. After realizing Egypt's concerns, Turkey was careful to articulate that its role was complementary to that of Egypt and that 'Turkey is not trying to steal a role from Egypt' (Dogan, 2009).

In the international arena, too, from time to time, there was reluctance to let Turkey play a more active third party role. Particularly during the George W. Bush administration, Turkey's facilitative mediation between Israel and Syria was not aided by the US (Sands, 2008; The Economist, 2008). Turkey was not a member of the Quartet despite its ambition to become so, and was only included in the Annapolis meeting at the last minute. Still, Turkey pushed to create a space for itself to play a facilitator role in the Arab-Israeli conflicts.

The second challenge emanates from how Turkey managed the mediation process. Note that earlier in this paper we argued that impartiality is an essential aspect of facilitation. Management of a fair process and smoothing out communication between the parties are the most sought after characteristics of a facilitator. Facilitative mediation was also where Turkey's strength lay. It was a country that had open communication channels and good relations with all the parties in the region after 2000. It was not perceived as part of regional alliance systems. As a result, Turkey implemented facilitative mediation successfully, especially during the Israeli-Syrian talks. What was expected from Turkey in this role was to contribute to the process of communication, which it did until the end of the indirect talks between Syria and Israel in 2008.

The feasibility of facilitative mediation is being debated today. After the Gaza operation of Israel in December 2008 and the Davos Summit of January 2009, Turkey's facilitation role has been jeopardized as relations with Israel have soured and relations 
between Hamas and Fatah have deteriorated. Turkey continued its ambition to play a third party role, but the nature of this third party role has been significantly transformed due to the recent developments. Turkey's biggest asset has always been the trust of the Israeli, Palestinian and Syrian governments. Recent developments have led to an erosion of impartiality and trust especially between Turkey and Israel, which in turn put the facilitator role in jeopardy.

Turkey's facilitative mediation is hampered due to several factors: difficulties in maintaining impartiality and the consequent erosion of trust, lack of clear delineation between facilitation and principal-power mediation, ineffective use of incentive mechanisms (especially reward mechanisms) in the process, structural challenges, and a mismatch between the preferences of the domestic constituency and the preferences of the parties. Overall we argue that most of these difficulties were revealed in the management of the facilitation process. We elaborate on each of these factors in the following paragraphs.

Some activities jeopardized Turkey's impartiality and the effectiveness of its facilitative role thus culminated in the erosion of trust on the Israeli side. As we noted earlier, for a facilitator the sine qua non characteristics are impartiality, credibility and the voluntary nature of its activities. It is these characteristics that make facilitation different from power mediation, which is often performed by 'interested' or 'principal' agents rather than 'disinterested' or 'neutral' ones. Until the Gaza operation in December 2008, most of the time Turkey managed to maintain its impartiality and credibility despite the overwhelming sympathy of the Turkish public opinion towards the Palestinian position.

However, although Turkey strove for facilitation, recently it engaged in practices that resembled more of a principal power mediator than a neutral facilitator. Oscillating between these two modes of mediation brought back the initial confusion about how Turkey defined its third party role: a principal mediator or a neutral facilitator. This confusion became apparent especially after the following two events. The first one was during the visit of Hamas leader in Syria Khalid Mashaal to Ankara. The second was during Turkey's handling of Israel's December 2008 Gaza operation. On both of these occasions Turkey could not successfully separate its own (including its domestic constituency's) interests from the disputing parties' interests, unlike what is expected from a neutral facilitator. The Turkish rhetoric that favoured neutral facilitation contradicted the practice that more resembled principal power mediation.

Khalid Mashaal's visit to Ankara in February 2006 created the initial question marks as to whether Turkey was satisfied with a facilitator role, or was in search of a more active, and perhaps a principal power mediator role. The invitation of Mashaal just after the Palestinian parliamentary elections was justified by an argument that he was invited for a consultation in order to give Hamas messages promoting peace and democracy, emphasizing their political responsibility, and the need to modify radical policies. Why Turkey chose to invite Mashaal instead of an elected Hamas leader from Gaza or the West Bank created further confusion about the achievement of these goals and the effectiveness of the facilitation process.

The tactic used during this visit was perceived as if Turkey was bargaining with one of the disputants to strike a side deal in which inducements are offered to the party to 
change its behaviour. This tactic meant shifting from a neutral facilitator role and leaning towards a power mediator role (for more on principal mediator tactics see Princen, 1992: 23-4). Yet the principal power mediator role was not played effectively because of insufficient incentives offered to the Hamas leadership to change its behaviour. The reward, which was recognition by Turkish authorities as a legitimate political actor, was provided right at the beginning without any condition or proof of behavioural change. Moreover, Turkey's invitation to Mashaal was undertaken without due consideration as to whether Turkey has enough power and resources to instigate such change in the Hamas leadership and whether Turkey possesses effective reward or punishment mechanisms to bolster the advice given to the Hamas leadership. Thus, what has been conveyed to Mashaal did not go much beyond rhetoric and verbal advice and was not adequately backed up by positive or negative inducements. Yet without an effective incentive mechanism, the principal power mediator role does not achieve much. On the contrary, this shift moved Turkey away from an effective facilitator role. The invitation to Mashaal was made without consulting with all relevant stakeholders in the process. More importantly, the action was taken to Israel's surprise. An effective facilitator role would have required designing a process diligently that could allow Turkey to explore the interests of Hamas, while at the same time keeping the other stakeholders and parties engaged in the process. This could have been more easily achieved through contacts that are not made public right away or through second track diplomacy where test signals could be sent out without incurring political risks. Such subtle channels of communication could also give Israel enough space for manoeuvre and face saving.

The second occasion, the handling of Israel's Gaza operation in 2008, further strained the neutral facilitation role. On this occasion, too, Turkey acted more like a principal power mediator by disclosing its self-interests openly and by using negative inducements on several parties to get them to change their behaviour. In the end, Turkey was successful in garnering Hamas support for a ceasefire agreement, but this happened at the expense of neutral facilitation. Therefore, Turkey opted for a principal power mediator role, especially by striking a side deal with Hamas, but this meant dropping its neutral facilitator characteristic and being trusted by all parties. At the end, the principal power mediation became limited to leveraging over Hamas.

As for the disclosure of self-interests, Turkish prime minister Erdogan displayed his rage openly in various statements during the Gaza operation; the best-known one being the outburst at the Davos meeting in January 2009. Erdogan was extremely concerned with the fact that the Israeli operation started immediately after Israeli prime minister Olmert's visit to Ankara where he discussed with his Turkish counterparts the last round of Israeli-Syrian talks. It was partly the mediator's self-interest in being 'dishonoured' that led Erdogan to respond in a very emotional manner.

Erdogan was caught by surprise when the operation started right after Olmert's departure. It was not only the feeling of betrayal but also disappointment regarding the future of the peace talks between Israel and Syria. During those days Erdogan and foreign minister Ali Babacan repeatedly gave briefings to the press reflecting their disappointment and perception of betrayal (Radikal, 2008a). Turkish decision makers did not disguise their surprise, disappointment and feelings of betrayal 
towards Israel (Bila, 2008). The result was that Erdogan described the Israeli operation in Gaza using statements like: 'crime against humanity', 'disrespectful behaviour against Turkey', 'we'll not take side with the oppressors' (Milliyet, 2009b) and 'massacre' while Babacan announced that all 'telephone communications with Israeli decision-makers were halted' (Radikal, 2008b). The most interesting of these criticisms which shows that the Gaza operation was interpreted rather personally was Erdogan's perception of Israel's operation as a 'disgrace towards Turkey'. Turkey considered the operation as such, arguing that the situation in Gaza was discussed by Olmert only a day before the operation started. Yet Turkish authorities were not informed and they felt that they and their peace efforts were not taken seriously by the Israeli authorities. The relations with Israel were further strained when anti-Israeli rhetoric and slogans dominated the AKP's party meeting at which Erdogan said the following:

While we were discussing the fifth round of the Israeli-Syrian talks, this operation happened. I consider this operation as an insult to Turkey despite all our efforts. I have to say this. For me, bombing unprotected civilians and saying that the operation's duration is unknown is a crime against humanity. (Radikal, 2008b; translation by the authors)

\section{Ali Babacan echoed:}

We stopped telephone diplomacy with Israel. You can't conduct peace negotiations on the one hand, while making war on the other. This is an attitude that damages the process initiated by Turkey. There is definitely inconsistency in this behaviour. If they had a war plan, why didn't they consult with us? This in fact damages our trust. When they were in Turkey 3-4 days ago, we talked about every issue, but they were preparing for war at the same time without informing us. This is not honest behaviour. (Radikal, 2008b; translation by the authors)

While Israel was being criticized, Erdogan went on a Middle East tour to discuss what could be done to end the war. The tour comprised visits to Syria, Jordan, Egypt, and Saudi Arabia (Turgut, 2009). On the tour Erdogan also met with the Palestinian leader Abbas but did not include Israel in the meeting. In addition to Turkey's disclosure of self-interest, the termination of dialogue with Israeli decision makers raised further questions about Turkey's neutral facilitator role. During that time Ali Babacan continued telephone diplomacy with Hamas, while terminating contacts with Israel. When asked why he spoke with Hamas he argued: 'Even under the most difficult circumstances it is important that communication channels be open. Our country talks with every party.' Yet the AKP government was criticized for not talking with their Israeli counterparts at the same time (Radikal, 2008c).

In response to criticism from inside Turkey and elsewhere that Turkey was openly taking sides and losing its ability to communicate with all parties, the AKP government reinitiated communication with Israel and emphasized the importance of its 
communication with Hamas for the sake of all in the conflict. Thus, some days later, Babacan consulted with his counterpart, Israeli foreign minister Tzipi Livni.

Throughout the Gaza operation Turkey's communication channels with Hamas remained open. These communication channels were used to convey messages between Hamas and international actors trying to find a ceasefire settlement (Radikal, 2009; Yeni Safak, 2009). Turkey carried messages between the US, European countries and Hamas to negotiate a ceasefire agreement. Such demands to convey messages came from various leaders like Condoleezza Rice and Nicholas Sarkozy. Erdogan's foreign policy advisor, Ahmet Davutoglu, was very actively meeting with all parties, including Khalid Mashaal of Hamas in Syria and the Israeli ambassador in Turkey, despite the tensions between Turkey and Israel at the prime ministerial level. More specifically, Erdogan and Davutoglu carried messages between the Western leaders such as Condoleezza Rice, Angela Merkel, and Tony Blair and the Israeli conditions conveyed by them to Hamas and vice versa in order to reach a ceasefire agreement (Milliyet, 2008, 2009a; Yeni Safak, 2009).

While Turkish-Israeli relations were strained due to Erdogan's harsh statements against Israel, at the same time Turkey was named in European circles as a potential member of an international mechanism to be established in Gaza to monitor weapons smuggling (Yeni Safak, 2009). European leaders seemed to be satisfied with Turkey's role in the Gaza crisis. Javier Solana, during his visit to Ankara, mentioned that 'Turkey has contributed to all important preparation works and to the decisions regarding our steps towards a ceasefire' (Hurriyet, 2009a).

Overall, Turkey's communication channels and close contact with Hamas leaders facilitated a ceasefire agreement. After the signing of the ceasefire agreement Davutoglu in a press briefing said that 'If a bilateral ceasefire was obtained yesterday [18 January], this was possible because of Turkey' and added that if that had not happened the summit of world leaders in Sharm al-Sheikh in Egypt would have been 'just a meeting with no results' (Dogan, 2009).

Turkey's active engagement with Hamas at the expense of its previous equidistant relations with all parties has cast doubt about the sustainability of its neutral facilitator role in not only the Israeli-Palestinian track but also the Israeli-Syrian track. By acting like a principal power mediator, Turkey limited its leverage and influence to Hamas only. Although this by itself was a useful third party role at the end, it was done at the expense of abandoning a neutral facilitator role. With this transformation, Turkey's third party role more resembled that of other principal mediators such as the United States, only with a more limited scope and without enough muscle to influence all of the parties in the dispute. A neutral facilitator, however, would have refrained from using inducements on the parties, would not have openly disclosed self-interest, and would have continued efforts to communicate with all stakeholders equally and serve as a face saving agent.

This new role was preferred neither by Israel nor by Syria and the PLO leader Mahmud Abbas. Both Bashar Assad and some Fatah leaders thought that Turkey could be more useful for Syria and Palestinians respectively if it maintained good relations and communication channels with Israel. ${ }^{5}$ In an interview given to the Turkish Daily Hurriyet, Assad said that 'if Turkey wants to help us with regard to 
Israel, Turkey should have good relations with Israel. Otherwise, how could Turkey play a role in the peace process?' (Hurriyet, 2009b)

After the Gaza operation, Turkey continued its principal power broker role by using negative inducements and leverage over the parties. This was apparent in the crisis that occurred between Turkey and Israel in October 2009 due to Turkey's veto of Israel's participation in a joint military exercise with the participation of some NATO members. The veto resulted in Israeli prime minister Benjamin Netanyahu's public declaration that Israel no longer desires the Turkish third party role and instead preferred to involve the French in further talks with the Syrians (Jerusalem Post, 2009a). Ahmet Davutoglu justified the Turkish decision as a 'negative inducement' given to Israel because of the difficulties raised by this country in conveying reconstruction aid to Gaza. Thus, this latest development too confirmed Turkey's aspiration to shift from a neutral facilitator to a principal power mediator. However, the critical question remains despite this aspiration: can Turkey assume a principal power mediator role effectively?

The only reason for the shift from neutral facilitator towards principal power broker should not be seen as solely based on the AKP government or Erdogan's actions. It is difficult to continue a neutral facilitator role when a significant portion of the domestic constituency has a clear preference on the issue. ${ }^{6}$ Public opinion was very supportive of the Palestinians in Gaza. Furthermore, the opposition parties, especially the nationalist MHP, criticized the AKP and Erdogan for being too soft on Israel (Sabah, 2009; Tumgazeteler, 2009; NTVMSNBC, 2010).

Although there was a consensus among political parties as to being concerned about the Palestinians, the government's policy was still criticized for being Hamas-oriented. Turkey's third party role in the Arab-Israeli conflicts, especially the Palestinian track, has become a part of the domestic political debate between the AKP and its critics. These intensified especially after AKP policies gave the impression of dealing only with Hamas at the expense of other parties in the conflict. Criticisms mainly focused on two points. The first is that the AKP's dealings with Hamas would isolate Turkey in the world, would encourage anti-Semitism and would bolster Islamic radicalism in Turkey (Ulsever, 2009). This criticism was also shared by the main opposition party, the Republican People's Party (Anka News, 2009). The second criticism revolved around the linkage regarding AKP's handling of the Kurdish political party in the Parliament, Peace and Democracy Party (Baris ve Demokrasi Partisi - BDP) and of Hamas. While Erdogan legitimizes contacts with Hamas by referring to its elected status, he refuses to negotiate with the elected BDP on the basis of its alleged links to the PKK terrorist organization. There were also concerns about the problems Turkey's Hamas policy could bring on Turkey regarding its struggle against the PKK (Oymen, 2009).

For future prospects, the Gaza operation and the recent flotilla crisis revealed that it will be very difficult for Turkey to resume a neutral facilitator role in the IsraeliArab conflicts. Even though for a while relations with Israel seemed to be repaired and largely put back on track after the Gaza war, at the moment they are under extreme strain and subject to great uncertainty. At least in the near future, Turkey's mediation ambitions would be limited to convincing Hamas and facilitating a dialogue between Hamas and Fatah. 


\section{Conclusion}

The post-Cold War environment, the regional vacuum in the Middle East, increasing political and economic assets, harmonization of foreign policy tools with those of the EU, having good relations with all parties in the region, combined with the eagerness of the AKP government led to the crafting of a new foreign policy vision regarding ArabIsraeli conflicts. This new vision materialized in Turkey's ambition to play active third party roles in these conflicts. After struggling with the definition and nature of this role, Turkey settled with facilitative mediation despite the existence of competing opinions among domestic actors about the nature of an appropriate third party role. Turkey performed a facilitative mediation role until the end of 2008. After that, this role began to evolve towards a principal power mediator role mainly due to the developments on the ground and the way Turkey chose to handle them. The principal power mediator role largely remained limited to convincing Hamas and employing negative inducements on Israel. However, the transformation from neutral facilitation was not a result of a consensus-based, conscious decision-making process, but rather developed ad hoc by the AKP government due to events on the ground, sensitivities of Turkish public opinion and concerns of the AKP leadership.

Limiting Turkey's third party contribution to Hamas eventually seemed to lead to a constructive result considering the Gaza ceasefire and may prove fruitful in the future given the fact that there are not many other countries that can use leverage over Hamas. However, for the same actor to maintain principal power mediator leverage over Hamas and carry out a neutral facilitation role between Israel and Syria and between Israel and all Palestinian parties simultaneously is problematic. Thus, Turkey will have to opt for either one of these roles. Moreover, so far Turkey has not convincingly demonstrated that it can use the incentive mechanisms over Hamas as a principal power mediator effectively. Simply, communication and open channels with the Hamas leadership do not necessarily mean that Turkey has sufficient leverage to change Hamas' behaviour.

Finally, there are serious domestic challenges that limit Turkey's third party engagement with Hamas. Part of the political elite that was critical of the AKP policies voiced discomfort with such a policy leaning towards Hamas and disregarding Fatah and Israeli interests.

Such strong drives emanating from Turkish domestic politics as well as the structure of relations between Turkey and all parties to the conflict made it even more challenging for Turkey to define a solid and stable third party role for itself in the Arab-Israeli conflicts.

\section{Notes}

1 The principles of this new policy agenda were articulated in several talks by Ahmet Davutoglu, such as in a public lecture 'Turkey's New Foreign Policy Strategies' at the Bruno Kreisky Forum, Vienna, Austria, 20 October 2008 (transcription can be accessed from http://www.kreisky-forum.org/pdfs/2008/2008-10-20. pdf). Although he did not use the term conflict resolution, the principles he mentioned as part of this new policy such as adopting a non-zero sum or win-win approach to relations with neighbors or taking societyto-society relations into consideration are compatible with a conflict resolution agenda.

2 Personal communication with a Turkish Ministry of Foreign Affairs official from the Middle East desk, April 2007 (for the military's view see Toksoz, 2009: 88). 
3 Although the literature argues that principal mediators are powerful and not neutral, in this figure we show that this is theoretically not impossible even if it is difficult to see in practice. Thus, we offer two categories of power mediation as 'interested' or 'principal' power mediation and 'disinterested' or 'neutral' power mediation.

4 For a more detailed account of 'conflict sensitive development' approach see the OECD guidelines (OECD, 1997; World Bank, 2005).

5 Personal communication with an ex-Fatah official, April 2007.

${ }^{6}$ During the Gaza crisis many anti-Israeli and pro-Palestinian rallies were organized throughout Turkey.

\section{References}

Altunisik, M. (2000) The Turkish-Israeli rapprochement in the post-Cold War era, Middle Eastern Studies, 36(1), pp. 172-191.

Altunisik, M. (2009a) Turkey-EU relations: creating new synergies in the Middle East, in: M. Comelli, A. Eralp \& C. Ustun (Eds) The European Neighborhood Policy and the Southern Mediterranean (Ankara: METU Press).

Altunisik, M. (2009b) Worldviews and Turkish foreign policy in the Middle East, New Perspectives on Turkey, 40, pp. 169-192.

Altunisik, M. (2010) Turkey: Arab perspectives, Foreign Policy Analysis Series, No. 11 (Istanbul: Tesev publications).

Anka News (2009) CHP'li Oymen Filistin'in yaninda olmak baska Hamas'in yaninda olmak baska (Oymen from CHP: there is difference between supporting the Palestinians and supporting Hamas), 6 January. Available at http://www.tumgazeteler.com/?a=4508201 (accessed 4 February 2010).

Aras, B. \& Karakaya Polat, R. (2007) Turkey and the Middle East: frontiers of the new geographic imagination, Australian Journal of International Affairs, 61(4), pp. 471-488.

Beriker, N. (2008) Conflict resolution: the missing link between liberal international relations theory and realistic practice, in: J. D. Sandole, S. Byrne, I. Sandole-Staroste \& J. Senehi (Eds) Handbook of Conflict Analysis and Resolution (New York: Routledge).

Bercovitch, J. (1992) The structure and diversity of mediation in international relations, in: J. Bercovitch \& J. Rubin (Eds) Mediation in International Relations: Multiple Approaches to Conflict Management (New York: St. Martin's Press).

Bila, F. (2008) Erdoğan'ın verdiği sert tepkinin iki nedeni (Two reasons underlying Erdogan's harsh response), Milliyet. Available at http://www.milliyet.com.tr/Yazar.aspx ?aType=YazarDetay\&ArticleID $=1034381 \&$ AuthorID $=61 \& b=$ Erdoganin $\% 20$ verdigi $\% 20$ sert $\% 20$ tepkinin $\% 20$ iki $\% 20$ nedeni\&a=Fikret\%20Bila (accessed 13 February 2010).

Carnevale, P. (2002) Mediating from strength, in: J. Bercovitch (Ed.) Studies in International Mediation (Basingstoke: Macmillan).

CNN Turk (2009) Eliezer CNN Turk'e Konustu (Eliezer spoke to CNN Turk). Available at http://www. cnnturk.com/2009/turkiye/11/23/eliezer.cnn.turke.konustu/552810.0/index.html (accessed 4 February 2010).

Commission of the European Communities (2003) Regular Report on Turkey's Progress towards Accession, Brussels. Available at http://ec.europa.eu/enlargement/archives/pdf/key_documents/ 2003/rr_tk_final_en.pdf (accessed 15 January 2009).

Commission of the European Communities (2006) Turkey 2006 progress report, Brussels, 8 November Available at http://ec.europa.eu/enlargement/pdf/key_documents/2006/nov/tr_sec_1390_en.pdf (accessed 21 July 2010).

Commission of the European Communities (2007) Turkey 2007 progress report, Brussels, 6 November. Available at http://ec.europa.eu/enlargement/pdf/key_documents/2007/nov/turkey_progress_reportS_en.pdf (accessed 21 July 2010).

Crocker, C., Hampson, F. \& Aall, P. (Eds) (1999) Herding Cats (Washington DC: USIP Press).

Cuhadar, Esra (2007) Turkey as a third party in the Israeli-Palestinian conflict: assessment and reflections, Perceptions, 12(1), pp. 89-108.

Davutoglu, A. (2001) Stratejik Derinlik (Istanbul: Kure Yayinlari). 
Davutoglu, A. (2008) Turkey's foreign policy vision: an assessment of 2007, Insight Turkey, 10(1), pp. 77-96.

Dogan, Y. P. (2009) Davutoglu says Turkey key to convincing Hamas on Gaza cease-fire, Today's Zaman. Available at http://www.todayszaman.com/tz-web/news-164558-davutoglu-says-turkey-key-to-convincing-hamas-on-gaza-cease-fire.html (accessed 13 February 2010).

Esmer, Y. (2009) Radikalism Asirilik ve Toplumsal Dergerler: Bir Saha Arastirmasinin Bulgulari (Radicalism, extremism and social values: findings from a nationwide survey), Talk given at Bahcesehir University, Istanbul, 30 May 2009.

Güven, E. (2001) Şık bir Hamle (An elegant move). Radikal Daily, Available at http://www.radikal.com. tr/haber.php?haberno=10812 (accessed 13 February 2010).

Heston, A., Summers, R. \& Aten, B. (2009) Penn world table version 6.3, (Center for International Comparisons of Production, Income and Prices at the University of Pennsylvania).

Hurriyet Daily (2009a) Turkey and the EU on the same waves, says Javier Solana, 9 January. Available at http://www.hurriyet.com.tr/english/domestic/10735803_p.asp (accessed 4 February 2010).

Hurriyet Daily (2009b) Israil'le iyi olmalisiniz (You have to be in good terms with Israel), Interview with Ertugrul Ozkok, 8 November.

Jerusalem Post (2001) Sharon to urge Turkey to pressure Arafat to put an end to violence, 8 August.

Jerusalem Post (2009a) PM says he prefers French mediation with Syria, 'Turkey has not strengthened image as honest mediator', 16 November.

Jerusalem Post (2009c) Lieberman: no peace agreement in this decade or next. FM also rules out Turkish mediation in talks with Syria, 28 December.

Keashly, L. \& Fisher, R. (1996) A contingency perspective on conflict interventions: theoretical and practical considerations, in: J. Bercovitch (Ed.) Resolving International Conflicts: The Theory and Practice of Mediation (Boulder and London: Lynne Rienner Publishers).

Kohen, S. (2001) Kolaylaştırıcı Rolü Zorlaşıyor (Facilitation role becomes difficult), Milliyet, 16 February

Kriesberg, L. (1996) Varieties of mediating activities and mediators in international relations, in: J. Bercovitch (Ed.) Resolving International Conflicts: The Theory and Practice of Mediation (Boulder, CO and London: Lynne Rienner Publishers).

Kriesberg, L. (2001) Mediation and the transformation of the Israeli-Palestinian conflict, Journal of Peace Research, 38(3), pp. 373-392.

Milliyet Daily (2005) Saron'dan BM'de Sartli Destek (A conditional support from Sharon at the UN), 3 May.

Milliyet Daily (2008) Erdogan Hamas'in talebini Ehud Olmert'e iletecek (Erdogan will convey Hamas demands to Ehud Olmert), 23 December.

Milliyet Daily (2009a) Hamas'in Ateskes sartlarini BM'ye tasiriz (We can convey the ceasefire conditions of Hamas to the UN), 4 January.

Milliyet Daily (2009b) Ankara'da Gazze Atesi (The Gaza fire hits Ankara), 7 January.

Murinson, A. (2006) The strategic depth doctrine of Turkish foreign policy, Middle Eastern Studies, 42(6), pp. 945-964.

NTVMSNBC (2010) Bahceli'den Erdogan'a Gazze sorusu (Bahceli posed a question on Gaza to Erdogan). Available at http://arsiv.ntvmsnbc.com/news/471321.asp (accessed 4 February 2010).

OECD (1997) OECD-DAC Guidelines on Conflict, Peace, and Development Cooperation. Available at http://www.oecd.org/document/32/0,3343,en_2649_33693550_33800800_1_1_1_1,00.html (accessed 13 February 2009).

Oymen, O. (2009) ‘CHP'li Öymen: Turkiye'nin Prestiji Zedelendi’ (Turkey’s prestige harmed) ntvmsnbc, Available at http://arsiv.ntvmsnbc.com/news/473841.asp (accessed 6 February 2010).

Princen, T. (1992) Intermediaries in International Conflict (Princeton, NJ: Princeton University Press). Radikal Daily (2005b) Gul: Guvenlik Duvarla Gelmez (Gul: the wall cannot bring security), 6 January Radikal Daily (2005a) Gul'un en hassas ziyareti (Gul's most sensitive visit), 4 January.

Radikal Daily (2008a) Erdoğan: Barışa darbe, Türkiye’ye saygısızlık (Erdogan: a blow against the peace and disgrace against Turkey), 28 December.

Radikal Daily (2008b) Gazze' de yapılanlar ciddi bir insanlık suçu (What is done in Gaza is a crime against humanity), 29 December. 
Radikal Daily (2008c) Babacan Hamas'la Temasta (Babacan is in touch with Hamas), 30 December.

Radikal Daily (2009) Rice'tan AKP'ye: Öyleyse Hamas'1 ikna edin (From Rice to AKP: then convince Hamas), 6 January.

Robins, P. (1991) Turkey and the Middle East (London: Pinter Publishers NY: The Royal Institute of International Affairs).

Sabah Daily (2000) Barak: Tesir gücünüzü kullanın (Barak: use your influence), 24 November.

Sabah Daily (2009) Bahceli'den Hukumete Elestiri (Criticism to the government from Bahceli), 20 January.

Sands, D. (2008) Mideast Israel-Syria talks hindered; peace deal would require more mediation by Bush team, The Washington Times, 25 July.

Siniver, A. (2006) Power, impartiality and timing: three hypotheses on third party mediation in the Middle East, Political Studies, 54, pp. 806-826.

Stern, P. \& Druckman, D. (Eds) (2000) International Conflict Resolution after the Cold War (Washington, DC: National Academy Press).

Toksoz, I. (2009) The Turkish military's perception of instability as an external threat and terrorism, Defence Against Terrorism Review, 2(1), pp. 73-99.

The Economist (2008) Two-track tango; Israel, Syria and the Palestinians, 24 May.

Tumgazeteler (2009) Bahceli: AKP Gazze'de Etkisiz Kaldi' (Bahceli: AKP was ineffective in Gazze). Available at http://www.tumgazeteler.com/?a=4571025 (accessed 4 February 2010).

Turgut, P. (2009) Turkey could be key player in Gaza peace, Time, Available at http://www.time.com/ time/world/article/0,8599,1870188,00htm (accessed 2 February 2010).

Ulsever, C. (2009) AKP ve Hamas (AKP and Hamas), Hurriyet, 15 January.

Vatan Daily (2002) Ortadogu'da Arabuluculuk icin Vakit Erken (It is not yet time to become a mediator in the Middle East), 23 January.

Vatan Daily (2005) Erdogan: Barış için Arabulucu Olabiliriz (Erdogan: we can be a mediator for the sake of peace), 3 May.

World Bank (2005) Social development papers: conflict prevention and reconstruction, Paper no. 27. Available at http://siteresources.worldbank.org/INTCPR/Resources/WP27_Web.pdf (accessed 13 February 2010).

World Bank World Development Indicators (2010) Available at http://data.worldbank.org (accessed July 2010).

Yanik, L. (2009) The metamorphosis of 'metaphors of vision': ‘bridging' Turkey's location, role and identity after the end of the cold war, Geopolitics, 14(3), pp. 153-170.

Yeni Safak Daily (2001) ABD, AB, BM ve Rusya Gucbirligi Yaptilar (US, EU, UN, and Russia join powers), 29 October.

Yeni Safak Daily (2009) İsrail'in ateşkes şartı Erdoğan'a iletildi (Israel's conditions for ceasefire were conveyed to Erdogan), 6 January.

Zaman Daily (2001) Arabulucu Olun (Be a mediator), 7 August.

Zaman Daily (2002) İsmail Cem yoğun telefon diplomasisi yürütüyor (Ismail Cem conducts intense telephone diplomacy), 8 April.

Zaman Daily (2008) Türkiye Filistin'de Barış kampüsü kuruyor (Turkey is building a campus for peace in Palestine), 3 May.

Zartman, W. \& Touval, S. (1996) International mediation in the post cold war era, in: C. Crocker, F. Osler Hampson \& P. Aall (Eds) Managing Global Chaos: Sources of and Responses to International Conflict (Washington, DC: United States Institute of Peace Press). 